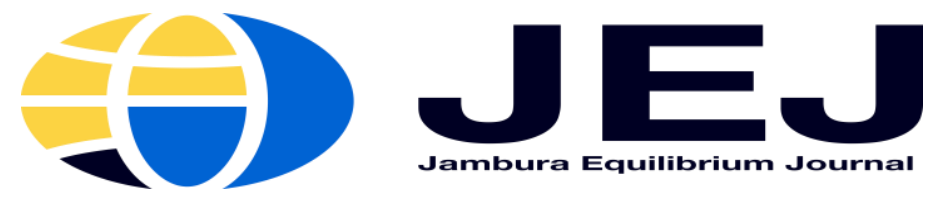

Volume 1. Number 2. July 2019

P-ISSN 2655-9110

E-ISSN 2656-0445

http://ejurnal.ung.ac.id/index.php/equij

\title{
Analysis Of Factors Affecting Corn Farmers 'Revenue In Gorontalo District
}

Wiwi Pratiwi ${ }^{1}$, Syarwani Canon ${ }^{2}$

Department of Economic Development, Economic Faculty, Gorontalo State University ${ }^{1}$

Faculty of Economics, Gorontalo State University ${ }^{2}$

\begin{abstract}
This study aims to determine what factors influence the income of corn farmers in Gorontalo district (case study of Poor Corn Farmers in Gorontalo District). The data in this study are primary data by distributing questionnaires to poor corn farmers in Gorontalo Regency. The data analysis technique in this research is multiple regression. The results of this study indicate that the factors that influence the income of poor corn farmers in Gorontalo District (1) simultaneously the area of farmer Education, number of dependents in the family, land ownership status and the use of technology in corn farming significantly influence the income of poor corn farmers) in Gorontalo Regency. (2) partially only land area and land ownership status have a significant effect on the income of poor corn farmers in Gorontalo Regency.
\end{abstract}

\section{Keywords: Income, Corn Farming, Poor Farmers}

The role of the agricultural sector in Indonesia is very important in making a major contribution to the development of economic growth and welfare of farmers. The role of the agricultural sector is as a source of producing basic needs, clothing and housing, providing employment, contributing to high national income, and providing foreign exchange for the country. Economic growth and welfare of farmers depends on the level of income of farmers and the benefits derived from the agricultural sector itself. The agricultural sector is a mainstay to improve the welfare of some Indonesian people because most Indonesians live in rural areas and work in the agricultural sector. The contribution of the agricultural sector in economic development lies in five terms, namely: providing an increasingly large food surplus to an increasing population, increasing demand for industrial products so as to encourage the need for secondary and tertiary sectors, providing additional foreign exchange earnings for the import of capital goods for development through the 
continuous export of agricultural products, increasing village income, and improving the welfare of rural people (jhingan, 2007., Saragih, 2010). Even in Gorontalo, the agricultural sector has greatly contributed in forming the Provincial GRDP. Seeing the large contribution of the agricultural sector in the economic growth of Gorontalo Province, it is proper for the government to pay more attention to the development of the agricultural sector.

One of the food crop commodities that can take a role in the development of the agricultural sector is the commodity of corn. In Indonesia, corn is the second food commodity after rice. In Gorontalo, corn is familiar because corn is a food substitute for rice, especially for rural farmers who have consumed corn if there is less rice.
Gorontalo Province has an area of $12,215.45 \mathrm{~km} 2(1,221,544 \mathrm{ha})$. Of this area, $36 \%$ is dry land which has the potential and is developed or cultivated for various crops, especially corn. Corn production in 2014 amounted to (719,780 tons) dry shelled, an increase of 50,686 tons (7.58\%) compared to 2013 production. The increase was due to an increase in harvested area of $(5.98 \%)$ or 8,393 ha and also increased productivity by ( $1.59 \%$ ) or 0.72 quintal / ha (Gorontalo provincial BPS, 2014). Besides being part of the agricultural culture, corn commodity has also become a potential export commodity in the future. In addition, the commodity of maize has also become a brand image for the Province as a producer of quality corn (Khairunnisa, et.al., 2014., Subroto, 2017., Ujami, 2016., Pali, 2016).

Table 1 Harvested Area and Production of Corn Food Plants by Regency / City, 2017

\begin{tabular}{|c|l|c|c|}
\hline No & \multicolumn{1}{|c|}{$\begin{array}{c}\text { region of the province } \\
\text { (district / city) }\end{array}$} & $\begin{array}{c}\text { Production } \\
\text { (ton) }\end{array}$ & $\begin{array}{c}\text { harvested } \\
\text { area } \\
\text { (hectare) }\end{array}$ \\
\hline 1 & Boalemo & 339.400 & 82.493 \\
\hline 2 & Gorontalo District & 449.301 & 94.764 \\
\hline 3 & Pohuwato & 482.645 & 104.676 \\
\hline 4 & Bone Bolango & 56.925 & 12.698 \\
\hline 5 & Northern Gorontalo & 223.459 & 41.312 \\
\hline
\end{tabular}




\begin{tabular}{|c|l|c|c|}
\hline 6 & Gorontalo City & 271 & 58 \\
\hline 7 & Gorontalo Province & 1.552 .001 & 336.001 \\
\hline
\end{tabular}

Source: Badan Pusat Statistik 2017

Table 1 shows that Gorontalo District is the second highest corn producer after Pohuwato Regency which is 449,301 tons. From the harvest area it has, it can potentially have the production of corn. Even though Gorontalo district is the second largest corn production center in Gorontalo province, Gorontalo district is the district that has the highest poverty rate among other districts in Gorontalo province, which amounted to 40.7 percent in 2017. Given that corn is a staple food as a substitute for rice for the people of Gorontalo. The importance of corn farmers to the people of Gorontalo does not promise farmers to be prosperous. Because, the existence of poverty problems still occur in farm families in some regions. Especially in rural communities. The External factors that make the income of corn farmers in Gorontalo have decreased due to several problems, including the price of corn that has not been stable because every harvest

\section{Demographics Based on farmer's income}

The lowest income from poor corn farmers is LN (natural log) 13.12 or IDR 500,000 and the highest is LN (natural $\log$ ) 15.07 or IDR $3,500,000$. The average value season arrives the price of corn becomes down from the time before harvest. Pests are also one of the reasons why farmers fail to harvest, which is becoming worse because of crop farming. There are many more problems experienced by farmers. So that the problem of poverty can be experienced by corn farmers in Gorontalo.

\section{METHODS}

The analytical method used in this study uses multiple regression methods so that the analysis used refers to the formulation of research objectives. The purpose of this study was to analyze the factors affecting the income of poor corn farmers in Gorontalo district. The variables in this study are land area (X1), education (X2), number of family members (X3), land ownership status (X4), technology (X5), and income of corn farmers (Y).

\section{RESULTS AND DISCUSSION}

of $\mathrm{LN}$ (natural $\log$ ) is 14.05 with a standard deviation of LN (natural $\log$ ) of 0.49 . The average value which is greater than the standard deviation shows that the average 
value can describe the income of poor corn

farmers in Gorontalo Regency.

Table 2 General Description of Respondents Based on farmers' income

\begin{tabular}{|c|c|c|c|c|c|}
\hline & $\mathbf{N}$ & Minimum & Maximum & Mean & Std. Deviation \\
\hline Income & 50 & 13.12 & 15.07 & 14.0015 & .49608 \\
Valid N (listwise) & 50 & & & & \\
\hline
\end{tabular}

Source: Data Processed 2019

\section{Demographics Based on Education}

There are 3 categories of education from farmers, where 39 people have elementary / equivalent education or $78.0 \%$. There are 7 farmers / junior high school graduates or $14.0 \%$. And farmers with a high school / secondary education as many as 4 people or at $8.00 \%$,

Table 3 Overview of Respondents by Education

\begin{tabular}{|c|c|c|c|c|}
\hline & Frequency & Percent & Valid Percent & $\begin{array}{c}\text { Cumulative } \\
\text { Percent }\end{array}$ \\
\hline SD/Sederajat & 39 & 78.0 & 78.0 & 78.0 \\
SMP/Sederajat & 7 & 14.0 & 14.0 & 92.0 \\
Valid & 4 & 8.0 & 8.0 & 100.0 \\
TMA/Sederajat & 50 & 100.0 & 100.0 & \\
\hline
\end{tabular}

Source: Data Processed 2019

Demographics Based on Number of dependents

All respondent farmers in Gorontalo Regency are dominated by farmers with a total of 4 dependents namely 15 farmers or $30.00 \%$ then the smallest frequency is farmers with a number of dependents 1 person, 2 people and 7 people namely as much as 1 person each farmers by $2.0 \%$. 
Table 4 General Description of Respondents by Number of dependents

\begin{tabular}{|c|c|c|c|c|}
\hline & Frequency & Percent & Valid Percent & $\begin{array}{c}\text { Cumulative } \\
\text { Percent }\end{array}$ \\
\hline 1 Orang & 1 & 2.0 & 2.0 & 2.0 \\
2 Orang & 1 & 2.0 & 2.0 & 4.0 \\
3 Orang & 13 & 26.0 & 26.0 & 30.0 \\
4 Orang & 15 & 30.0 & 30.0 & 60.0 \\
5 Orang & 14 & 28.0 & 28.0 & 88.0 \\
Valid & 3 & 6.0 & 6.0 & 94.0 \\
6 Orang & 1 & 2.0 & 2.0 & 96.0 \\
8 Orang & 2 & 4.0 & 4.0 & 100.0 \\
8 Orang & 50 & 100.0 & 100.0 & \\
\hline
\end{tabular}

Source: Data Processed 2019

\section{Demographics Based on Land Status}

All farmers who became respondents in Gorontalo District were dominated by farmers with the status of the sharing of land as many as 28 people or
$56.0 \%$ and the smallest frequency was that the status of the land owned by as many as 22 people or $44.0 \%$ of the total study sample.

Table 5 General Description of Respondents by Land Status

\begin{tabular}{|c|c|c|c|c|c|}
\hline & & Frequency & Percent & Valid Percent & $\begin{array}{c}\text { Cumulative } \\
\text { Percent }\end{array}$ \\
\hline \multirow{3}{*}{ Valid } & Bagi Hasil & 28 & 56.0 & 56.0 & 56.0 \\
\hline & Milik Sendiri & 22 & 44.0 & 44.0 & 100.0 \\
\hline & Total & 50 & 100.0 & 100.0 & \\
\hline
\end{tabular}

Source: Data Processed 2019

Demographics Based on Technology

Usage

There are 2 categories of technology use from farmers, where the number of farmers who do not use technology is 43 farmers or $86.0 \%$. And those who use technology are 7 respondents or with a percentage of $14.0 \%$. 
Table 6 General Description of Respondents Based on Technology Usage

\begin{tabular}{|c|c|c|c|c|}
\hline & Frequency & Percent & Valid Percent & $\begin{array}{c}\text { Cumulative } \\
\text { Percent }\end{array}$ \\
\hline $\begin{array}{c}\text { Tidak } \\
\text { Menggunakan } \\
\text { Valid }\end{array}$ Menggunakan \\
Total
\end{tabular}

Source: Data Processed 2019

\section{Multiple Regression Equations}

Table 7 Results of Multiple Regression Analysis

\begin{tabular}{|c|c|c|c|c|c|}
\hline $\begin{array}{l}\text { Dependent Variable: P } \\
\text { Method: Least Squares } \\
\text { Included observations: }\end{array}$ & $\begin{array}{l}\text { endapatan } \\
50\end{array}$ & & & & \\
\hline Variable & Coefficient & Std. Error & t-Statistic & Prob. & \\
\hline $\mathrm{C}$ & 12.95965 & 0.281484 & & & 46.04048 \\
\hline 0.0000 & 0.491333 & & 3.443721 & 0.0013 & \\
\hline Luas_Lahan & 0.047009 & 0.142675 & 0.492093 & 0.6251 & \\
\hline Pendidikan & 0.050963 & 0.095528 & 1.143314 & 0.2591 & \\
\hline JTK & 0.489978 & 0.044575 & 4.183068 & 0.0001 & \\
\hline Status_Lahan & 0.054129 & 0.117134 & 0.317306 & 0.7525 & \\
\hline Teknologi & & 0.170589 & & & \\
\hline R-squared Mean & 0.438423 & dependent var & 4.00150 & & \\
\hline justed R-squared S.D. & 0.374608 & dependent var & & 0.496078 & \\
\hline S.E. of regression & 0.392307 & Akaike info & riterion & 1.078624 & \\
\hline Sum squared resid & 6.771819 & Schwarz cri & rion & 1.308067 & \\
\hline F-statistic & 6.870163 & Durbin-Wat & on stat & 1.818263 & $\begin{array}{l}\log \\
-20.96559\end{array}$ \\
\hline Prob(F-statistic) & 0.000082 & & & & Quinn criter. \\
\hline
\end{tabular}

$\begin{array}{ll}\text { likelihood } & \text { F-statistic } \\ \text { Hannan- } & \text { Prob(F-statistic) }\end{array}$

Source: Eviews, 2019

Based on the numbers in the Unstandardized Coefficients column, the multiple regression equation is as follows:

$$
\begin{aligned}
& \hat{Y}=12,959+0,491 X_{1}+0,047 X_{2}+ \\
& 0,050 X_{3}+0,489 D 1+0,054 D 2+e
\end{aligned}
$$

Based on the analysis obtained tcount for the variable land area of 3.443 . When compared with the ttable value of 2.015. Then the $\mathrm{t}$ count obtained is far greater than the value of $\mathrm{t}$ table. The 
significance value of land area is smaller than the probability value of $0.05(0.0013$ $<0.05)$, then Ha1 which states that the area of land affects the income of poor corn farmers in Gorontalo Regency is accepted. So it can be concluded that at the $95 \%$ confidence level (alpha 0.05) the area of land has a positive and significant effect on the income of poor corn farmers in Gorontalo Regency.

Based on the analysis obtained tcount for the farmer Education variable of 0.492. When compared with the ttable value of 2.015 . Then the tcount obtained is smaller than the ttable value. The significance value of farmer education is greater than the probability value of 0.05 (0.6251>0.05), so Ha2 which states that farmer education influences the income of poor corn farmers in Gorontalo Regency is rejected. So it can be concluded that at the 95\% confidence level (alpha 0.05) the education of farmers has a positive but not significant effect on the income of poor corn farmers in Gorontalo Regency.

Based on the analysis, the value of tcount for the variable number of dependents in the family is 1,143 . When compared with the ttable value of 2.015. Then the tcount obtained is far smaller than the value of ttable. The significance value of land area is greater than the probability value of $0.05(0.2591>0.05)$, then $\mathrm{Ha} 3$ which states that the number of dependents in the family has an effect on the income of poor corn farmers in Gorontalo Regency is rejected. So it can be concluded that at the 95\% confidence level (alpha 0.05) the number of dependents in the family has a positive but not significant effect on the income of poor corn farmers in Gorontalo District.

Based on the analysis obtained tcount for the variable land ownership status of 4.183. When compared with the ttable value of 2.015 . Then the tcount obtained is greater than the ttable value. The significance value of land ownership status is smaller than the probability value of $0.05(0.0013<0.05)$, then Ha4 which states that the status of land ownership affects the income of poor corn farmers in Gorontalo Regency is accepted. So it can be concluded that at the $95 \%$ confidence level (alpha 0.05) the status of land ownership has a positive and significant effect on the income of poor corn farmers in Gorontalo Regency.

Based on the analysis obtained tcount for the variable use of technology in corn farming by 0.317 . When compared with the ttable value of 2.015. Then the tcount obtained is far smaller than the value of ttable. Significance value The use of 
technology in corn farming is greater than the probability value of 0.05 , or the value (0.7525>0.05), then Ha5 which states that the use of technology in corn farming affects the income of poor corn farmers in Gorontalo Regency is rejected. So it can be concluded that at a 95\% confidence level (alpha 0.05) the use of technology in corn farming has a positive but not significant effect on the income of poor corn farmers in Gorontalo Regency.

\section{CONCLUSION}

Simultaneously farmer education area, number of dependents in the family, land ownership status and the use of technology in corn farming together have a significant effect on the income of poor corn farmers) in Gorontalo Regency.

Then the results partially found factors that influence the income of poor corn farmers in Gorontalo Regency that (1) land area has a positive and significant effect on the income of poor corn farmers in Gorontalo Regency, (2) farmer education has a positive but not significant effect on farmer's income poor corn in Gorontalo Regency, (3) the number of dependents in the family has a positive but not significant effect on the income of poor corn farmers in Gorontalo Regency, (4) land ownership status has a positive and significant effect on the income of poor corn farmers in Gorontalo Regency, (5) the use of technology in corn farming has a positive but not significant effect on the income of poor corn farmers in Gorontalo Regency.

\section{SUGGESTION}

1. Corn farmers are expected to be more open in finding and absorbing appropriate technology so that the resulting production is getting better and the need for the role of related agencies to conduct training in the use of technology to farmers. Then for farmers it is also necessary to take action in the form of intensification of agricultural land in increasing corn production because it is difficult to increase production inputs for land by increasing the availability of land due to relatively expensive land prices.

2. In an effort to increase production, the government should be more intense in conducting counseling related to efforts to maximize production with better input production efficiency. Then besides that there is a need to mitigate the risk of corn farming for the prevention of crop failure. Then further maximize the technical implementation of the Special Efforts PAJALE Program Specific Hybrid Corn Commodities in 
Gorontalo District, especially those relating to assistance and reviewing the benefits of the bargaining position of corn farming with the existence of this program.

\section{REFERENCES}

Jhingan, M.L. 2007.Ekonomi Pembangunan dan Perencanan. Jakarta: Raja Grafindo.

Khairunnisa.2014. Pengaruh Factor Social Ekonomi Terhadap Pendapatan Petani
Jagung.Skripsi. Universitas Muhammadiyah Sumatera Utara. Saragih. 2010. Agribisnis: Paradigma Baru Pembangunan Ekonomi Berbasis Pertanian. IPB Press. Bogor.

Subroto R. 2017. Kontribusi Usaha Ttani Jjagung Terhadap pendapatan Rumah Tangga Petani di Desa Huidu Utara Kecamatan Limboto Barat Kabupaten Gorontalo.Skripsi. Fakultas Pertanian, UNG. 